International Research Journal of Management, IT \& Social Sciences
Available online at https://sloap.org/journals/index.php/irjmis/
Vol. 7 No. 6, November 2020, pages: 153-Xx
ISSN: 2395-7492
https://doi.org/10.21744/irjmis.v7n6.1031

\title{
The Reality of Government Communication in Hitu Lama Negeri Development Planning, Central Maluku Regency
}

\author{
Pahrul Idham Kaliky ${ }^{\text {a }}$ \\ Marno Wance ${ }^{\mathrm{b}}$ \\ Muhammad Yahya Matdoan
}

\section{Article history:}

Submitted: 27 September 2020

Revised: 18 October 2020

Accepted: 09 November 2020

\section{Keywords:}

communication;

customary government;

development;

personal communication;

saniri institution;

\begin{abstract}
This research was to understand the reality of development communication in Hitu Lama Negeri, Central Maluku Regency. The purpose of this research is to determine the communication barriers of the Saniri Negeri and Government institutions in planning the development of the country. The results of the study, it found that obstacles to development planning caused conflicts of national interest, namely (1). Some of the people/residents of Negeri Hitu Lama have experienced a decline in the trust of the head of the existence of the Traditional Institution (Saniri Negeri) so that it hinders development planning. (2) Planning for the development of Hitu Lama Negeri still has conflicts of interest, institutional egos, causing delays in development planning. The development communication pattern used is the local customary approach like the state government carries out personal communication with customary institutions to build harmony in carrying out development planning.
\end{abstract}

International research journal of management, IT and social sciences (C) 2020. This is an open access article under the CC BY-NC-ND license (https://creativecommons.org/licenses/by-nc-nd/4.0/).

Corresponding author:

Marno Wance,

Universitas Pattimura, Nusaniwe, Indonesia.

Email address: marno.wance@fisip.unpatti.ac.id

\footnotetext{
a Universitas Pattimura, Nusaniwe, Indonesia

${ }^{\mathrm{b}}$ Universitas Pattimura, Nusaniwe, Indonesia

Universitas Pattimura, Nusaniwe, Indonesia
} 


\section{Introduction}

The traditional government system is a cultural value that is noble and civilized and can be used to succeed in development. This concept is in line with what was stated by Kushandajani (2015), that the Maluku people have several customary organizations that are very suitable for use in government administration, development, community development, and empowerment of village communities. It means that within the scope of government, the management and utilization of natural and human resources as a source of village income and village development management patterns, where the priority scale refers to the physical village and the mental attitude of the community (Moelijarto, 1989). We see Sansiri's role in governance, development, community development, and empowerment of rural communities. This existence is following its existence in the structure of state and customary government which was considered still relevant because the King as the head of the state government, carries out his main duties, functions, and responsibilities. The kingdom also has the power as administrators of government, development, and society as part of the governance structure of the law Negeri (Rhodes, 2000; Frederickson, 2005).

Innitially, Nor-Hisham \& Ho (2016), said that the existence of these two customary institutions is merely decoration or complement to the customary government structure and has no meaningful role in the implementation of administrative tasks such as the implementation of public service tasks or in implementing community empowerment programs, but only functions in solving customary problems that occur in the country customary country. It seems that it is far from the expectations of all elements of indigenous peoples who expect their authority in various areas of the life of indigenous peoples. That expectation is far greater than what is mandated in the law. So that it becomes the basis for state recognition of the diversity and uniqueness of village customary communities as a special autonomous community. In connection with this issue Steenbergen (2013), stated that the involvement of Saniri and Soa will be further studied as actors in government administration, in the preparation of development programs, community development, and in the implementation of rural community empowerment programs, and if possible also involved in financing the program (Granger, 1988; Williamson et al., 1997). For this reason, the indicators used are: (a) Whether or not Saniri has public services, (b) Whether or not Saniri's role in the preparation of development programs, (c) Whether or not Saniri's role is in formulating community development programs and empowering village communities, and (d) Whether or not Saniri's role in determining program financing.

The results of research conducted by Touwe et al. (2020), the results of this study show that (1) there is a mutual agreement on the enforcement of customary provisions, but now it is divided. (2) Initially, the government and society were consistent in implementing customer provisions in the election of a king. However, now the community has undergone a change in customs regarding the election of a king. (3) community support for the current customary provisions has divided as a result of differences of opinion. (4) community obedience to all customer decisions has changed due to political interests. Besides, the findings of research conducted by Wance et al. (2020), concluded that Hila State administration and Saniri institutions have not yet optimized the governance of the Hila Village development planning.

How to describe the pattern of relationships between the Customary Institution (Saniri) and the Head of Affairs and the Head of Section in government administration, coaching, community empowerment, and empowerment of rural communities? This issue according to Che \& Qian (1998), requires further study of the existence of law institutions and village governance, especially the structure of state government, especially those related to the implementation of government tasks in general. It is because there is an impression of injustice in the use of the village/law country budget to finance law government tasks, which seem much smaller (Gottschalk, 2009; Jaeger $\&$ Bertot, 2010). Even fund is almost not provided, with general government tasks that have managed the apparatus of the Kaur and Kasi. This condition will have implications for the lack of or disharmony that occurs between the Customary Institutions (Saniri and Soa) and the Heads of Affairs and Section Heads in the future administration of the country's government. On these considerations, we use facilities, includes; a) the village budget for financing the duties of law institutions, (b) the village budget for funding the responsibilities of customary government and general government, (c) Saniri for government administration, and (e) support law institutions for the administration of government

This page should begin with the introduction of your article and follow the rest of your paper. Wilson (1990), stated that the Introduction explains the scope and objective of the study in the light of current knowledge on the subject. 


\section{Materials and Methods}

Descriptive research is a way to identify the characteristics of a method that focuses on observation, natural conditions, and the researcher acts as an observer, categorizes behavior, observes symptoms, and records them in an observation book (Kriyantono, 2014). In line with the description above, Meleong (2008), explains that qualitative research is easy to adapt to field conditions, is more sensitive to changes in patterns or values in the field, then to sharpen the picture of the phenomenon under study, direct interpretation of the phenomenon or event receives a high priority in qualitative research over the analysis of measurement data. Thus qualitative research produces descriptive data in the form of written or spoken words from people and observed behavior. This way described by Danim (2002), is based on the view and assumption that human experience is obtained through interpretation. Objects, people, situations, and events do not have meaning by themselves but through their analysis. This step is in line with the thoughts of Sugiyono (2007), which explains that the data validity test in qualitative research includes credibility (internal validity), external validity transferability, dependability (reliability), and confirmability (objectivity) tests.

This study used qualitative research is aimed at finding the problems to be studied, or to get an overview of the role Saniri and Soa in the implementation of governance, development, fostering social and community empowerment, how is the task owned Indigenous Institute (Saniri and Soa) in customary land governance systems, as well as how to describe the pattern of relations between the Traditional Institutions (Saniri and Soa) and the Heads of Affairs and Section Heads in government administration, development, community development, and empowerment of the Old Hituese people.

\section{Results and Discussions}

\section{The Reality of Traditional Institutions Communication in the Era of Regional Autonomy}

According to Cheema and Rondinelli (in Syaukani H. R et al., 2002), there are at least four reasons that constitute the rationality of decentralization, which are cited as follows;

1) Decentralization can bypass the complex and procedural bureaucratic routes of the central government.

2) Decentralization allows representation of various political, ethnic, religious groups in the development and broadens equity in allocating resources and investment.

3) Decentralization is needed to institutionalize community participation from planning, implementation to development evaluation.

4) Decentralization can deliver flexible, innovative, and creative government administration so that local governments have the opportunity to innovate and experiment with policies in particular regions without having to agree with the central government.

Furthermore, Gie (1979), states the reasons for the implementation of decentralization in governance in Indonesia, are;

1) Cultural reasons, differences in various factors in Indonesia are very diverse and complete so that it is difficult to control problems due to differences in the central government. Therefore, it is necessary to carry out a full autonomous regional government to manage the diversity of each region.

2) Reasons for state awareness and development. With the local government that can directly interact with the people, the people will feel they have a high nationality and participate without restrictions.

The country is the lowest form of a local government institution in Maluku Province, which still has customary rights, historical origins, customs, and village culture. Another institution in the village/country is the Village/State Community Empowerment Institution (SCEI). This institution has the duty and function of planning, executing, and controlling development based on the will of the people in the Village/State stipulated in the Village/Country Regulation. These institutions are functioning as partners of the Government in the village/country in the administration of governance, development, and community activities are so useful.

\section{The Reality of Traditional Institutions Communication in National Development}

Communities are more likely to choose to solve their problems through law institutions as informal institutions than other village government institutions as formal institutions. In line with that, Soekanto (1990), argues that customary

Kaliky, P. I. ., Wance, M. ., \& Matdoan, M. Y. . (2020). The reality of government communication in hitu lama negeri development planning, Central Maluku Regency. International Research Journal of Management, IT and Social Sciences, 7(6), 153-160. https://doi.org/10.21744/irjmis.v7n6.1031 
institutions formed to manage the enforcement of customary law, especially regarding legal issues such as land rights. (Aslan, 2019; Aslan \& Yunaldi, 2018; Aslan \& Putra, 2020). According to Salim (2010), it explained that the development process, including environmental management that takes place in a customary area, must pay attention to customary law or old norms that developed in the community. Compliance with customary law is a control mechanism for human behavior and actions. The existence of local organizations / traditional institutions is colored by traditional values, which by Lerner in Moelijarto (1989), is considered as the forces that bring about changes in society towards the justice of the community itself.

Communication Patterns, according to Batten (1957), is a process where the village community first discusses to determine their wishes before doing something according to the agreement. For example, the problem of village development is collective action in the sense of working to combine material and spiritual spirits (Moelijarto, 1989; Ryan et al., 1986; Chan, 1998; Suwandana, 2019). Regarding the importance of progress in rural areas, this is the opinion of Talizudhu (1991), which is very relevant, which states that efforts to develop villages based on recognition of the essential role played by villagers for a long time ago. So as has been suggested by Siagian (1982), that the government functions as a stabilizer of cultural economy, innovator, new thought, as a pioneer in various aspects of life. Thus, village development needs a fully participatory village government.

The proven ability of Saniri to mobilize the community in development has been essential. The crucial elements in village development were stated by Abdullah (1982), state that the implementation of progress is that of balanced community participation and government guidance. Thus, the approach to village development is social, participation from below, and organization where it's implementation-oriented towards the initiative, creation, and collective community itself, which requires a policy-making mechanism that is as good as possible, achieved. Because of the development of the living standard and welfare is determined by the community. Siagian (1982), also argues that the participation of the wider community is necessary because they are the ones who ultimately carry out various activities in development, people play a role as the subject and object. The success of village community development is influenced by a variety of factors, which include: funds, the physical condition of the village, leadership personnel, and other factors. According to Moelijarto (1989), the success or failure of village community development renewed cultural, political, and administrative values.

Village development requires that these community members be aware of their rights to articulate through existing media, be aware of their obligations as citizen-oriented and participate in input structures and processes and do not merely expect output without participation in the input process. The success of the development was determined by identification, orientation, and public perception. The success of village development, the indicator can be used as benchmarks. If the economic value that is productive, consumption, and high per capita growth are highlighted. But if the socio-political field is to be prioritized, the institutional structure will be formed with prominent role differentiation. Likewise, in the field of culture with various attitudes following increasingly advanced and complex situations. (Kartodirdjo, 1989). According to Talizudhu (1991), the development of village communities is said to be successful if;

1) Active community participation in development;

2) A sense of community responsibility for development;

3) The ability of rural communities to develop can be improved (grown);

4) When the physical infrastructure can be built and maintained;

5) When a harmonious living environment can be built and maintained.

According to Tan and Koentijoroningrat in Zuraida \& Rizal (1993), states that three things need to be considered for the success of a reform effort, especially in rural areas: a) The results of the reform efforts must be seen concretely in a short time, b) The renewal effort must be seen as beneficial to the community concerned, c) These efforts must not conflict with the cultural value system and norms that are still in force in the community's concern. This third thing means knowledge of the social and cultural conditions of the community's concern.

The principle of village development is carried out through the efforts of the government and the community itself. Because considering the various levels of village development, with different customs and community life with different characteristics of the population, it is necessary to have appropriate village management following the level of customs, life, and characteristics of the villagers concerned with village management. villages can develop to a higher level (advanced). The implementation of village management aims to:

1) To make village development effective and efficient through planning, implementing, and supervising village development as well as possible.

2) Mobilizing people to carry out development efforts under the policies and direction of the government. 
3) Generating community participation in supporting the development efforts of the government employing motivation.

4) Coordinate the activities of informal leaders and synchronize them with activities or formal leaders. 5. Forming village institutions deemed necessary as a means of implementing village management and leadership (Rais \& Simulie, 2000).

In the context of the formulation of village development planning. Ideally, it is also expected to be carried out in a transparent, effective, and accountable manner, and in a participatory manner. In this context, according to village secretary Hitu Lama, that: "Regarding the village development planning process held in the Hitu Lama country, it is carried out transparently and accountably, and involves active community participation. So that various programs proposed by the community can be adjusted according to the available budget capacity and prioritized according to community conditions. Of course, various programs can involve the community and have a positive impact on improving the welfare of the people in the Hitu Lama country. With the power and authority possessed by the village head or the king, the village budget management process is implemented under various rules set, both by the central government and by the local government. The village fund management process, which has been determined by the local government, is divided into three aspects, namely, its use for development, governance, and community empowerment. Of course, a larger percentage is on community empowerment. The various provisions governing the management of the village fund budget carried out the village head or the king and his apparatus.

Apart from that, it is related to community participation, from the planning process to the implementation of the program, all of which involve active community participation. Meanwhile, about the law enforcement process, it shows that avoid irregularities in the management of the Village Fund Budget, an effective supervisory mechanism is implemented both internally from the Raja Raja or the village head, as well as from the district government. In the context of the Hitu Lama country, there has not been any fraud or actions that harm village, regional, or state finances. It can see in the avoidance of village officials from various actions that lead to legal proceedings so that the Hitu Lama country according to the Regent of Central Maluku is used as a pilot village for all villages in Central Maluku, in this context, there are five pilot villages designated by the Maluku Regent. Middle (Results of interviews with Bapak Raja, and village secretary, on 31 August, at the King's House).

The influence of the leadership of the village head or king, who is the traditional leadership, in the context of political, social, economic, and cultural interactions with the community, the influence is very significant. It can see in the leadership style applied to the community in influencing political perceptions and behavior, as well as community participation in various activities or activities organized by the village government. Both in political processes and economic and cultural context are so important. It is especially true for youth participation, in village development, and in empowering village communities. According to the Secretary of the Hitu Lama Village, the village apparatus having sufficient capacity and competence as well as experience in providing public services to the community, and in the management of village government, as well as the implementation of development, the village apparatus is also facilitated with various adequate facilities and technology. It can see in the existence of a representative village office, which is right next to the king's house, and various equipment such as the availability of various computers. The availability of sophisticated and adequate technology is helpful for the Hitu Lama Government apparatus in completing various tasks, especially in the process of accountability for the village fund budget to the central government and the Central Maluku government).

Various answers from respondents emphasized that even though mobilization has contributed to the improvement of public awareness to actively participate in supporting and being involved in the implementation of development programs in this village. Therefore, the progress of the level of active community participation is an important aspect to be considered in the development of various activities, including national development activities that are currently actively implementing development. For this reason, the first step that needs to be taken is to build or develop public awareness so that they voluntarily and consciously participate actively with the state government and elements of existing law institutions, to work together and be responsible for implementing and maintaining the results better.

Therefore, the role of the state Saniri adat institution which is given sufficient authority politically to formulate various public policies in its territory needs to accurately take into account the complexity of the needs of the community in every plan of national development activities to encourage the community to participate in supporting activities in his village. It can be said that the village development in Hitu Lama, Leihitu District, Central Maluku Regency is smooth. It can answer the needs of the community according to the expectations of all parties, presumably it is also influenced by the improvement of the Traditional Institution (Saniri) to carry out its role properly and the

Kaliky, P. I. ., Wance, M. ., \& Matdoan, M. Y. . (2020). The reality of government communication in hitu lama negeri development planning, Central Maluku Regency. International Research Journal of Management, IT and Social Sciences, 7(6), 153-160. https://doi.org/10.21744/irjmis.v7n6.1031 
improvement of members of the Saniri institutions. In understanding their duties and functions with the implementation of development activities that have been stipulated in the existing village work plan.

\section{Conclusion}

The communication pattern of community development through law institutions, namely human resources (HR) in state Saniri institutions, cannot yet absorb the aspirations of the people in Hitu Lama Country. Communication patterns that have absorbed in development programs have resulted in a lack of good relations between Saniri institutions, the community, and the state government. The form of decision making in Saniri and government institutions is that there is no harmonious communication relationship between law institutions and the community and government apparatus of the Hitu Lama Negeri in carrying out the tasks of the country's development planning. The static pattern of communication at state government level institutions is a factor in obstructing communication across institutions in Negeri Hitu Lama, Central Maluku Regency.

\section{Conflict of interest statement}

The authors declared that they have no competing interests.

\section{Statement of authorship}

The authors have a responsibility for the conception and design of the study. The authors have approved the final article.

\section{Acknowledgments}

Our gratitude goes to Pattimura University for providing motivation and enthusiasm in publishing research results in international journals. 


\section{References}

Abdullah, T. (1982). Agama, etos kerja dan perkembangan ekonomi.

Aslan, \& Putra, P. (2020). Dampak Islamisasi terhadap Agama dan Kebudayaan Lokal di Paloh, Kalimantan Barat, dalam Buku "Agama \& Budaya Nusantara Pasca Islamisasi (Vol. 1). eLSA Press.

Aslan, A. (2019). Pergeseran Nilai Di Masyarakat Perbatasan (Studi tentang Pendidikan dan Perubahan Sosial di Desa Temajuk Kalimantan Barat).

Aslan, A., \& Yunaldi, A. (2018). Budaya Berbalas Pantun Sebagai Media Penyampaian Pesan Perkawinan Dalam Acara Adat Istiadat Perkawinan Melayu Sambas. Jurnal Transformatif (Islamic Studies), 2(2), 111-122.

Batten, T. R. (1957). Communities and their development: an introductory study with special reference to the tropics. Oxford University Press.

Chan, K. (1998). Mass communication and pro-environmental behaviour: waste recycling in Hong Kong. Journal of environmental management, 52(4), 317-325. https://doi.org/10.1006/jema.1998.0189

Che, J., \& Qian, Y. (1998). Institutional environment, community government, and corporate governance: Understanding China's township-village enterprises. Journal of Law, Economics, \& Organization, 1-23.

Danim, S. (2002). Menjadi peneliti kualitatif.

Frederickson, H. G. (2005). Whatever happened to public administration? Governance, governance everywhere. The Oxford handbook of public management, 282-304.

Gie, T. L. (1979). Cara belajar efisien: Sebuah buku pegangan untuk mahasiswa. Gadjah Mada University Press.

Gottschalk, P. (2009). Maturity levels for interoperability in digital government. Government information quarterly, 26(1), 75-81. https://doi.org/10.1016/j.giq.2008.03.003

Granger, C. W. (1988). Some recent development in a concept of causality. Journal of econometrics, 39(1-2), 199211. https://doi.org/10.1016/0304-4076(88)90045-0

Jaeger, P. T., \& Bertot, J. C. (2010). Transparency and technological change: Ensuring equal and sustained public access to government information. Government Information Quarterly, 27(4), 371-376. https://doi.org/10.1016/j.giq.2010.05.003

Kartodirdjo, S. (1989). Respon Pada Penjajahan Belanda di Jawa: Mitos dan Kenyataan. Prisma, XIII(11), 3-11.

Kriyantono, R. (2014). Teknik praktis riset komunikasi. Prenada Media.

Kushandajani, K. (2015). Implikasi UU No. 6 Tahun 2014 tentang Desa Terhadap Kewenangan Desa.

Moelijarto, T. (1989). Pembangunan Negara Berkembang, Aplikasi, Praktek dan Teori. PPs UGM.

Moleong, L. J. (2008). Metodologi Penelitian Kualitatif eds. Revisi. Bandung: PT Remaja Rosdakarya Offset.

Nor-Hisham, B. M. S., \& Ho, P. (2016). A conditional trinity as 'no-go'against non-credible development? Resettlement, customary rights and Malaysia’s Kelau Dam. The Journal of Peasant Studies, 43(6), 1177-1205.

Rais, K., \& Simulie, Dt. P. (2000). Hukum Adat Serta Akibat-Akibat Hukumnya. Rajawali Pers.

Rhodes, R. A. (2000). Governance and public administration. Debating governance, 5490.

Ryan, E. B., Giles, H., Bartolucci, G., \& Henwood, K. (1986). Psycholinguistic and social psychological components of communication by and with the elderly. Language \& Communication, 6(1-2), 1-24. https://doi.org/10.1016/0271-5309(86)90002-9

Salim, E. (2010). Ratusan bangsa merusak satu bumi. Penerbit Buku Kompas.

Siagian, S. P. (1982). Organizational leadership and Behaviour organization.

Soekanto, S. (1990). Sosiologi keluarga tentang ikhwal keluarga, remaja, dan anak. Rineka Cipta.

Steenbergen, D. (2013). Negotiating the future of local 'backwaters': Participatory marine conservation on small Islands in Eastern Indonesia (Doctoral dissertation, Murdoch University).

Sugiyono, S. (2007). Metode Penelitian Kualitatif Kuantitatif dan R \& D. Bandung Alf.

Suwandana, I. G. M. (2019). Role of transformational leadership mediation: effect of emotional and communication intelligence towards teamwork effectiveness. International research journal of management, IT and social sciences, 6(2), 52-62.

Syaukani, H. R., Gaffar, A., \& Rasyid, M. R. (2002). Otonomi daerah dalam negara kesatuan. Kerjasama Pustaka Pelajar [dan] Pusat Pengkajian Etika Politik dan Pemerintahan.

Talizudhu, N. (1991). Pembangunan Desa dan Administasi Pembangunan Desa. Yayasan Kaiya Dhama.

Touwe, M. A., Tuanaya, W., \& Wance, M. (2020). Sistem Pemilihan Raja Negeri Munarten Kecamatan Taniwel Kabupaten Seram Bagian Barat. Jurnal Studi Ilmu Pemerintahan, 1(2), 1-15.

Wance, M., Muhtar, M., \& Kaliky, P. I. (2020). PKM Penyelenggaraan Pemerintahan Dalam Perencanaan Pembangunan Negeri Hila Kabupaten Maluku Tengah. CARADDE: Jurnal Pengabdian Kepada Masyarakat, 2(2), 229-338.

Kaliky, P. I. ., Wance, M. ., \& Matdoan, M. Y. . (2020). The reality of government communication in hitu lama negeri development planning, Central Maluku Regency. International Research Journal of Management, IT and Social

Sciences, 7(6), 153-160. https://doi.org/10.21744/irjmis.v7n6.1031 
Williamson, A. M., Feyer, A. M., Cairns, D., \& Biancotti, D. (1997). The development of a measure of safety climate: the role of safety perceptions and attitudes. Safety science, 25(1-3), 15-27. https://doi.org/10.1016/S09257535(97)00020-9

Wilson, J. (1990). Politically speaking: The pragmatic analysis of political language. B. Blackwell.

Zuraida, D., \& Rizal, J. (1993). Masyarakat dan manusia dalam pembangunan: pokok-pokok pikiran Selo Soemardjan. Pustaka Sinar Harapan. 